\title{
PALEONTOLOGY AND ENVIRONMENTAL JUSTICE: MAKING CONNECTIONS THROUGH POLITICAL ECOLOGY
}

\author{
Camila Neves Silva \\ Angélica Cosenza
}

I Professor in the Department of Geosciences at the Federal University of Juiz de Fora - UFJF, PhD student in Education Graduate Program in Education - PPGE / UFJF, Juiz de Fora, MG, Brazil.

(D) II Professor at the Faculty of Education and Graduate Program in Education at the Federal University of Juiz de Fora - PPGE / UFJF, Coordinator of the Study and Research Group in Environmental Education - GEA / UFJF, Juiz de Fora, MG, Brazil

\begin{abstract}
Far from studying only beings from the past, Paleontology is a current science which can situate human existence in the context of the global environmental crisis before inequalities and socio-environmental conflicts which occur in Brazilian paleontological sites. Aiming to discuss possible connections between Paleontology and Environmental Justice, this essay arises from a survey on environmental conflicts existing in the paleontological sites in Minas Gerais. Stemming from the issues found and the contribution of the Political Ecology theoretical framework, the struggle for territory and decoloniality is discussed as crucial dimensions for a view that seeks to restore the populations' right to their (paleo) territories. The connections between these fields are presented here as references for the fight against the social inequalities found in paleontological sites, such as those in Minas Gerais, and for the inclusion of their communities in participatory management.
\end{abstract}

Keywords: Environmental Conflicts; Paleontological Sites; Political Ecology.

São Paulo. Vol. 24, 2021

Featured Topic:

Decolonial Insurgences and Emancipatory Horizons: Contributions of Political Ecology

DOI: http://dx.doi.org/10.1590/1809-4422asoc20200089r2vu2021L3AO 


\section{Introdução}

This study consists of a theoretical essay that seeks to discuss possible relations between Paleontology and Environmental Justice through the Political Ecology field. In an attempt to understand key issues related to environmental conflicts in paleontological sites in Minas Gerais, we started from the vulnerabilities existing in these places to weave connections we believe are essential to overcome a possible neutrality in the Paleontology field, as well as a strategy to resist and confront the mercantilization of these sites and the socio-environmental inequality found in these places.

Bursting in the middle of the 20th century, the environmental crisis arose as an ecological crisis originated by the unsustainable way of life in which the rationale of modernity sees (and treats) the environment as an obstacle to development (GODINHO et al., 2016; LEFF, 2016). Environmental degradations are multiplying, highlighting the need to rethink human societies' way of life in relation to nature, power relations, social actions and ethical values (LEFF, 2016). Along with environmental degradation, social problems on a global scale are accentuated, in which natural resources and human beings are seen as necessary commodities for profit accumulation. The ecological crisis is thus linked to a capitalist crisis, with which it shares the same dynamics, in a way-of-life crisis (LÖWY, 2013).

In this degradation context, its global character also makes it a civilizational crisis, a knowledge crisis, as advocated by Leff (2016). For the author, more than identifying its causes, a change of thought is necessary to build a new social rationale, a new ecological order capable of linking natural processes to socio-environmental complexity, in a unification between Natural Sciences and Social Sciences. In this essay we discuss how Paleontology can take part in this process.

Considering its etymology, Paleontology, as the study of ancient beings (from the Greek palaios = "ancient"; onto = "being"; logos = "study"), concerns the history of fossils (from the Latin fossilis = "extracted from the earth") through remains or traces of beings from the past, generally preserved in rocks (CARVALHO, 2004). The constant search for the registration of these beings, which can be used to date the rocky strata in which they are contained, allows the reconstruction of the Earth's geological history, the understanding of the evolution and the processes of emergence and extinction of species, and also the perception of changes occurred over time on the planet. But this science goes further, by making it possible to understand events, such as climate change and tectonic plates movements, which continue to be processed in the present day (CARVALHO, 2004).

As it also concerns the emerging sustainable tourism industry ${ }^{1}$ (including geotourism), the studies associated with the hydrocarbon industry, among other issues, Paleontology is a science located at the interface between Geosciences and Biology, and can be considered an interdisciplinary science, which connects Natural Sciences to

1- This tourism market segment envelopes, according to Moura-Fé (2015), adventure tourism, rural tourism, ecotourism and, most recently created, geotourism, a field related to ecotourism, but emphasizing the physical/abiotic mediums. 
Human Sciences (CARVALHO, 2004). Furthermore, it is also inserted in the lives of many Brazilians who live in fossiliferous areas, to whom these fossils can contribute with their notion of belonging to the environment and with the constitution of possibilities for community-based tourism (SCHOBBENHAUS, 2002).

Since it is related to Environmental Sciences, Paleontology cannot be seen apart from the ecological debate. That is because, while there are positive changes in the relationship between paleontological sites and the surrounding communities, there are also possible negative changes, such as the exclusion of these communities when considering the profit from touristic activities (managing offices and companies are the destination of most of the capital), or distancing from their traditional practices, as well as physical/ environmental damage, due to the flow of visitors, and also loss of the feeling of belonging on the part of local residents (LOPES, 2008).

Even though belonging has many possible definitions, we consider this term here according to the cultural geography bias, for which it involves, in the first instance, the place, but also the community sphere and the feeling of attachment, maintaining the cohesion of a community (CARDOSO et al., 2017). The feeling of belonging is "looking at and recognizing oneself" as part of a society with its own cultural characteristics, including symbols, moral and ethical values (CARDOSO et al., 2017, p.89). As it is related to culture and the singularities experienced in a given place, belonging might also involve conflicting relationships, when there is destruction of elements which link a community to its place, its rooting (CARDOSO et al., 2017).

Another socially important issue that occurs in paleontological sites consists of the mining activity, commonly associated with these areas because the rocks themselves, where fossils are found, in general, have commercial value. Environmental impacts, arising from mechanized extraction techniques, include silting and dumping of waste into water bodies, fossils destruction, conflicts with local activities and environmental protection areas, and end up causing degradation and social problems such as removal and dissatisfaction of local residents (SINTONINI et al., 1994 apud SANTOS; CARVALHO; FERNANDES, 2010). They may also experience the destruction of their ways of life, in a process that, according to Cardoso et al. (2017) can be called deterritorialization, and which promotes a rupture of the feeling of belonging with the place (we will discuss other implications of the term later). Thus, conflicts emerge in these areas (SANTOS; CARVALHO; FERNANDES, 2010).

Additionally, areas of paleontological interest are susceptible to social problems generated by the illegal collection and commercialization of their fossils, which fuels smuggling and its associated risks (SANTOS; CARVALHO; FERNANDES, 2010). In Brazil, there is no specific legislation to protect this heritage (MARTINS, 2016), although the fossil trade has been forbidden since 1942 (BRASIL, 1942), when extractions were allowed only by the National Department of Mineral Production - DNPM (Brazilian initials), currently called National Mining Agency - ANM (Brazilian initials) (BRASIL, 2017). Since the Federal Constitution of 1988, in its article 216 (BRASIL, 1988), fossils are considered Cultural, Educational and Scientific Heritage, but we still rely on fragile 
laws or decrees.

Environmental conflicts in these areas, therefore, arise from the denunciation of environmental inequality by co-present social subjects, with environmental perception and exposure to different risks. Issues of origin in the Environmental Justice and Political Ecology fields help to ponder on how this scenario is representative in a conjuncture in which the contemporary environmental crisis is linked to damages related to the hegemonic model of society, announcing environmental injustices (SANTOS, 2006; LEFF, 2016).

When we think about environmental injustice, it is inevitable to refer to the environmental justice movement. Started in the United States, it brought up discussions about the inseparability between society and the environment, problematizing disputes in the midst of vulnerability situations associated with environmental risks (BULLARD, 2005). The movement, which was established in the 1980s, encouraging reflections on the ways of elaborating policies and making decisions on the environmental issue, since they are a reflection of the hegemonic relations taking place in the predominant society and its institutions, conferring privileges to some and harming socially vulnerable groups (BULLARD, 2005), as is the case in paleontological sites where unequal disputes involving the use and occupation of the territory are present.

In the context of injustices, domination and control of nature have led to objectification of communities in vicinities of paleontological sites. As the environmental crisis is inserted in a civilization crisis scenario, it is important to think about the advocacy of what Escobar (2017) calls "decoloniality", meaning the need for a real liberation from intellectual colonization (of knowledge) and from the power of a modern-colonial worldsystem (epistemological legacy of Eurocentrism), through the search for new alternatives, other modes of knowledge (counter-hegemonic) and power.

Deconstructing power and knowledge, causing a continuous positioning by means of critical dialogue, is one of the objectives of Political Ecology, a field that for Alimonda (2017), although recent and branched, has its own characteristics, stemming from a Latin American perspective in the search for an identity. Such a view starts from the multiplicity of nations which struggle for decolonization, for the end of the domination of a Eurocentric reductionist episteme, which considers Europe as an active place whereas places in the Global South, such as America, are considered as passive ones (LANDER, 2005; SANTOS, 2006). It is also an eco-political turn when studying socioenvironmental conflicts and the contribution of social movements for environmental justice (MARTÍNEZ-ALIER, 2015).

As many paleontological sites are in state of environmental conflicts, mainly due to the (uneven) dispute over territory, which occurs among different actors (SILVA; COSENZA, 2019b), it is important to emphasize the risks to which these populations are subjected, even when the feeling of belonging to territories characterized by the presence of fossils is often detached from these populations (OLIVEIRA, 2018). Hence, we advocate thinking Paleontology considering local socio-environmental issues, in connection with the fields mentioned.

For this purpose, we started from the discussion about data collected from a sur- 
vey on paleontological sites in Minas Gerais - MG (SILVA; COSENZA, 2019a) and the relationships occurring in these places, in addition to the search for the source of the articles used for the referred survey. The choice for the state of Minas Gerais owed to the great visibility of some of these places both in the scientific and tourist sceneries, as well as the number of paleontological sites in the state, since out of the 42 sites recognized and registered by the Brazilian Commission of Geological and Paleobiological Sites (SIGEP [Brazilian initials]), 4 are located in MG. Such a survey was fundamental for the emergence of conflicting and belonging relationships or paleontological sites valorization.

The resignification of this look also aims to act in counterpoint to hegemonic interpretations that Paleontology receives when associated with environmental issues. In this respect, discussions about the Anthropocene have been growing, as a basis to explain the changes our planet has been undergoing, with one species (Homo sapiens), for the first time, being actively responsible for a new epoch in the geological time scale. Coined in the 1980s, the term emerged to designate a new era, in which a new human (anthropo- = "human" and -ceno = "new") produces climatic and geological changes and high rates of extinction (HARAWAY, 2016).

But this term and its definition have been attracting criticism (HARAWAY, 2016; IGLESIAS-RÍOS, 2019). For better exposing power relations, global and local relations and conflict relations, Capitalocene could be a more appropriate term (HARAWAY, 2016; IGLESIAS-RÍOS, 2019). This term emerged so as to highlight that placing the blame and responsibility for environmental changes on the human species, or on individual actions, is far from the solution, since it is necessary to consider that forces are unequal and diverse, demanding a more critical understanding of the problem (IGLESIAS-RÍOS, 2019).

Hence, we situate ourselves in the reflexive exercise of critically analyzing the possible (and necessary) correlations among Paleontology, Environmental Justice and Political Ecology. We hope that such a composition contributes to a new look, turned to alternative ways of thinking about Paleontology, as well as the relationships established in paleontological sites, contributing to the visibility of their conflicts, vulnerabilities and environmental injustices, in addition to the right of their communities to territories, combined with nature conservation. How these relationships can be established are shown subsequently.

\section{Paleontological sites in Minas Gerais state: socio-environmental vulnerabilities}

The state of Minas Gerais has a great diversity of paleontological sites, under different conditions. A paleontological site is a fossiliferous location which gathers characteristics worthy of safeguard actions, in general by public power (SCHOBBENHAUS et al., 2002). The fact that a region constitutes a site does not mean that it is automatically protected, but that it deserves to be preserved, since the safeguard is only given by a specific law (municipal, state or federal). For geoparks ${ }^{2}$, the status is given by UNESCO

2- According to Brilha (2009), a geopark is a well-delimited geographical territory and constitutes a development strategy based on the preservation of the geological heritage, including all the other elements of the natural and cultural heritage. 
(United Nations Educational, Scientific and Cultural Organization).

The survey performed by Silva and Cosenza (2019a) on the occurrence of fossils in Minas Gerais revealed four paleontological sites, one sedimentary, stratigraphic and paleoenvironmental site, in addition to a speleological site of paleontological importance, already listed and published by the Brazilian Commission of Paleontological Sites - SIGEP (Brazilian initials). It is worth mentioning that one of the sites, located in the Gandarela Basin (municipality of Rio Acima), is not yet listed, but was inserted in the analysis of the authors as it is protected by municipal law and for being included in the area of the Quadrilátero Ferrífero Geopark, aspiring UNESCO Global Geopark.

The sites surveyed were: 1) Gandarela Basin; 2) Fonseca Geosite, in the Fonseca Basin; 3) Conophyton de Cabeludo, in the Vazante Formation; 4) Sumidouro do Córrego do Carrapato Site; 5) Peirópolis and Serra da Galga, in the Marília Formation (Bauru Basin); and 6) Carte de Lagoa Santa Speleological Site, in the Sete Lagoas Formation (Bambuí Group). While some are tourist spots, like the last two, also associated with teaching and research centers, another, like the Paleontological site of Fonseca, also has the possibility of becoming a point of tourist interest on account of the proposal to create the Quadrilátero Ferrífero Geopark, not yet approved. Considering the analyzed sites, 4 are located in mining areas: Gandarela Basin, Conophyton de Cabeludo, Sumidouro do Córrego do Carrapato and Carste de Lagoa Santa (Figure 1). All six sites are of interest to the scientific community as places for collecting geological and paleontological material.

There are issues in common among the data collected, such as the mischaracterization of local traditions after the sites in Peirópolis and Carste de Lagoa Santa were opened to tourism, deficient infrastructure for the surrounding community itself (paving and lighting of roads, public transport, poorly planned septic tanks and irregular waste disposal areas) and dispute among mining companies, local residents and managers of conservation units - CUs (which can be seen in Figure 1). There are also problems related to youth unemployment and exodus, water and soil contamination and housing in risk areas (DEUS et al., 1997; LOPES, 2008; SANTOS; CARVALHO; FERNANDES, 2010; PADOAN; SOUZA, 2013 apud SILVA; COSENZA, 2019a). 
Figura 1: Sites of paleontological importance in Minas Gerais in vicinity of mining areas and conservation unities - CUs
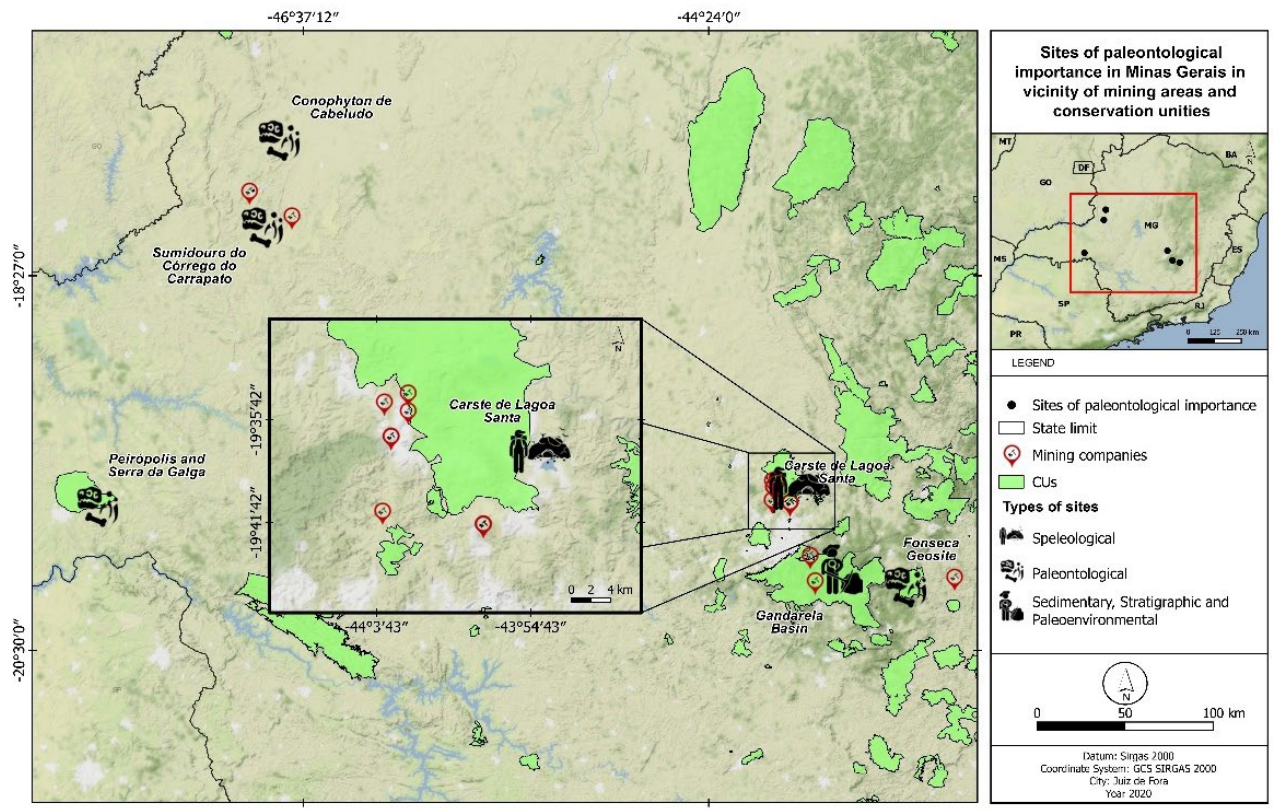

Source: elaborated by the authors, 2021.

The Gandarela Basin, in the municipality of Rio Acima, whose main fossils are vegetables and stromatolites aged between 53 and 23 million years old, is experiencing conflicts resulting from the divergence of interests in the use and appropriation of the natural environment among mining, society and CUs. Meanwhile, the Peirópolis Site, in Uberaba (Triângulo Mineiro), where dinosaurs, crocodylomorphs, fish, invertebrates, among others, aged between 90 and 70 million years old, can be found, after a long legal dispute over the use and occupation of the territory among mining, population and scientists, is currently in a stable situation in which there are no more active mining companies. However, Peirópolis faces issues such as lack of infrastructure in urbanization, sanitation, cleaning, security and health professionals, besides changes in local culture, essentially focused on paleontological tourism today (LOPES, 2008; SANTOS; CARVALHO; FERNANDES, 2010).

The Vazante Formation, where the Conophyton de Cabeludo Site is located, in the northwest of the state, aged between 1.6 billion years and 950 million years, is important for the study of Conophyton stromatolites on a world scale. The municipality of Vazante directly experiences physical issues caused by mineral exploration, such as cracks in houses, opening of craters, destruction of caves by water contamination, contamination by heavy metals, desertification of soils and pollution in general. Similar problems are 
those of Lagamar (neighboring the municipality of Vazante), where the Sumidouro do Córrego do Carrapato Site is located, with stromatolites of the same age as in Vazante (SILVA; COSENZA, 2019a) and also in mining area.

In the Fonseca Basin there are several fossil angiosperms aged between 65 and 33 million years. In the municipality of Alvinópolis, in the Fonseca Geosite, central-eastern part of the state, the impacts of agricultural expansion and disordered urbanization can be exemplified by frequent floods and predatory timber extraction. There is economic interest in the area due to deposits of canga and lignite (SILVA; COSENZA, 2019a).

The speleological site inserted in the Carste of Lagoa Santa Environmental Protection Area (EPA), in the south-central part of Minas Gerais, presents problems which are very similar to those described above, in the municipalities where its caves are located: Lagoa Santa, Pedro Leopoldo, Matozinhos and Cordisburgo, known for the countless fossils found in the region (such as mammals of the Brazilian megafauna, at least 10,000 years old) including hominids, such as Luzia.

In Lagoa Santa, the problem is similar to that of the Gandarela Basin, with conflicts between the $\mathrm{CU}$ and the surrounding communities, whose free access was prohibited (PADOAN; SOUZA, 2013 apud SILVA; COSENZA, 2019a), with conflicts also generated by the disordered occupation of the soil, with destruction of sites of archaeological and paleontological interest. As in Cordisburgo, young people migrate due to the fact that tourist attractions do not favor the employment of the local population in their activities (SILVA; COSENZA, 2019a).

In Pedro Leopoldo and Matozinhos, in turn, the main problems consist of pollution and contamination, in the first municipality, due to mining and, in the second one, by steel industry. Irregular disposal of garbage was found and conflicts occur between farmers and quilombolas, like those in Pedro Leopoldo, who have been asking, for years, for recognition, implementation of basic urban infrastructure and basic health services, as found by Silva and Cosenza (2019a) in the Map of Environmental Conflicts in the State of Minas Gerais (Study Group on Environmental Issues - GESTA / UFMG [Brazilian initials]).

The environmental conflicts highlighted help to understand how the use and appropriation of natural resources take place in regions of paleontological importance, where social relations are main issues, enhancing the urgency for a participatory democracy, a process far from what has been happening in these places. This is what happens, for example, at Sumidouro State Park, at Carste de Lagoa Santa EPA, where conservation interests on the part of park managers are different from social dynamics and the community's perception of this management (PADOAN; SOUZA, 2013). Local residents cannot use and do not have free access to the $\mathrm{CU}$ area. They previously used it for leisure, religious events and firewood collection, but were not consulted about its creation, revealing the ineffectiveness of the management process which commonly occurs in natural environments (PADOAN; SOUZA, 2013).

In order to discuss more accurately the relationships involved in the paleontological sites in question, we need to better understand the scope of terms such as territory and environmental conflict, which are recurring here. 


\section{Territory, Paleoterritory and Environmental Conflict: a view to the specificities of paleontological sites in Minas Gerais}

Defining territory through an approach about space, the term involves power relations, being the result of shared identities and relations of belonging, unique to this space. According to the definition of territory advocated by Rogério Haesbaert (2003), the integration of diverse dimensions of the territory allows an integrating perspective of this concept, such as political, cultural, economic and naturalist dimensions, which starts from relationships (and not from dualism) between society and nature. For Haesbaert (2003), when defining territory, it is important for us to consider it as an instrument of power and a value that also permeates the symbolic, in an identity-existential valorization.

It can be said, however, that the relations (including conflictive ones) concerning the same territory do not occur in a uniform way for the human societies which occupy/ occupied these spaces. In Paleoterritories, for instance, we find different characteristics of use and occupation of the same territory in different moments over time (SOLÓRZANO; OLIVEIRA; GUEDES-BRUNI, 2009). The investigation of the transformation processes caused by overlapping uses of the territory, and their use by past populations, allows us to understand impacts and their effects on the current landscape (SOLÓRZANO; OLIVEIRA; GUEDES-BRUNI, 2009).

The analysis of the Paleoterritories makes it possible to understand the social context in which territory changes occurred and to understand the importance of past populations' knowledge on a given environment, in search of their survival (OLIVEIRA, 2018), in different time and space scales. Paleoterritories thus overlap, forming, at the same time, a single and multiple reality (OLIVEIRA, 2018).

The communities living in paleontological sites thus occupy non-neutral territories, configured by historical, natural, economic, cultural and political elements. Hence, linked to the assimilation of multiple practices which affirm the place, the conception of territories involves meanings based on such elements, although the meanings attributed may be altered by globalization, with groups being made invisible by capitalist models (GODINHO et al., 2016). And it is precisely in this defense of the place as a social, political and ecological issue, that the struggle for the right to exist is linked to the notion of conflicts.

Even though the term conflict may have different meanings, environmental conflicts are a struggle against what Acselrad (2010) defines as ecological modernization imposed by capitalism. Developmental projects generating environmental conflicts involve expropriation or environmental impacts which prevent the maintenance of socio-cultural and socio-environmental aspects, in cases of communities excluded from the projects (GODINHO et al., 2016). Conflicts enhance situations of environmental injustice, with environmental conflict as a driving force for the defense of the place (ZHOURI; LASCHEFSKI, 2010).

Although there is a tendency to unify different types of conflicts when discuss- 
ing environmental issues, Zhouri and Laschefski (2010) propose three modalities under which these conflicts can be investigated. They are: 1) distributive conflicts, which arise from social inequalities both in the access and in the use of environmental goods, such as water and energy; 2) spatial conflicts, which occur due to environmental impacts and their effects, when they cross the boundaries between territories of different agents or social groups, whose conflicts do not necessarily arise associated with territorial disputes (for example, emission of pollutants); and 3) territorial conflicts, which occur due to the capitalist appropriation of the territorial base of social groups and are characterized by involving groups with different modes of production in their territories. Frequently, this type of conflict occurs on account of the divergence of interests between the urbanindustrial-capitalist-hegemonic society and local communities, which have their identity in the territory and the assurance of production and reproduction of their ways of life.

Such categorization of conflicts helps us to look at the conflicts that happen on account of the socio-environmental vulnerabilities highlighted in the paleontological sites in Minas Gerais. Certainly, this type of classification has its limits, as emphasized by Zhouri and Laschefski (2010), but it allows visualizing the best strategies for coping with and resolving these conflicts. Moreover, it is also possible that several types of conflict are happening at the same time, in a given location, which seems to be common for our paleontological sites. Let us regard, thereafter, a possibility of categorizing the conflicts we brought up in this essay.

For being in areas where a dispute between mining and society takes place, the Gandarela Basin and the Carste of Lagoa Santa Speleological Site can be grouped in the modality of territorial conflicts. Both also present conflicting relationships between CUs and the surrounding residents. It cannot be forgotten, however, that in the Carste of Lagoa Santa EPA, the municipalities of Pedro Leopoldo and Matozinhos, for being targets of problems such as pollution and contamination of soil, water and air, can also be attributed to the category of spatial conflicts.

Pedro Leopoldo, owing to social inequalities in access and use of natural resources by quilombolas, can also be part of the category of distributive conflicts. This is because, in addition to the struggle for the recognition of Quilombo de Pimentel, its residents defend the conservation of the water sources in their area, access to energy and paving and the implementation of Public Policies for the Promotion of Racial Equality in the municipality.

The Fonseca Geosite, on the other hand, due to disordered agricultural and urban expansion, suffers from flooding, which do not necessarily occur directly in the waste disposal area. Thus, we have opted here for attributing this conflict to the modality of spatial conflicts. Conflicts in Conophyton de Cabeludo and at the Sumidouro do Córrego do Carrapato Site can also be considered spatial, which, for being close to each other, have problems in common, such as pollution and contamination of water, soil and air. As they are in areas where a dispute over territory happens between society and mining companies, they can also be classified in the category of territorial conflicts.

Finally, Peirópolis has no problems with mining today, but it lacks urban infrastructure and basic health services, which leads us to classify the area within distributive 
conflicts, although local memory and identity may have been harmed by past territorial conflicts.

We notice here that, although they have the singularities described, the territorial conflicts in these paleontological sites in general involve processes of deterritorialization and reterritorialization, common to territorial conflicts. According to Zhouri and Laschefski (2010), the process of deterritorialization concerns the displacement or removal of groups, with land loss, which disrupts the community, damaging, among other aspects, its memory and identity. For Haesbaert (2003), this deterritorialization, which must be considered in its social sense, can actually be seen as a process of intensification of territorialization, since the act of territorialization is, firstly, to create spatial mediations which confer power in relation to certain individuals and social groups. In other words, the process involves creation and destruction of territories at their various scales, which may harm or even prevent the resumption of ways of life (ZHOURI; LASCHEFSKI, 2010).

Such remarks help to problematize the existing relationships between these territories and the knowledge that takes place in them, causing new epistemologies to emerge from differences (PORTO GONÇALVES, 2008). Environmental conflicts serve as a source of inspiration to theorize about ways to overcome socio-environmental problems, which Santos (2006) considers a challenge in a framework of environmental crisis. That is why, also considering other meanings, Political Ecology constitutes itself as a field that strains discourse on the environmental issue (LEFF, 2016), as we will discuss below.

\section{Thinking about Environmental Conflicts in paleontological sites in Minas Gerais: pathways through Political Ecology and Environmental Justice}

Often, from a conservationist perspective, public use in protected areas can restrict conservation to a marketing perspective, which considers only visitors as public, excluding local communities (VALLEJO, 2013). But a protected area, such as a paleontological site, is not just a geographically delimited space, which includes visitors, managers and service providers, since it is necessary to treat territoriality as a social construction, considering conflict as a central theme (VALLEJO, 2013).

Further incentive to popular participation is necessary to safeguard natural wealth. For Vallejo (2013), one of the most striking negative impacts in these areas consists of limitations of access imposed on older residents by environmental agencies, while these individuals, frequently, need these areas for their subsistence, which can be linked to extraction for small-scale agriculture, inside and outside its legal limits in Conservation Units. For the areas surveyed in this work, associated with CUs, not even local residents' leisure use of the place is allowed (PADOAN; SOUSA, 2013; SILVA; COSENZA, 2019a).

It is a challenge to reconcile natural wealth conservation, income generation and life improvement with low environmental impact, for the elaboration of public policies. Vallejo (2013) observes that since the beginning of the visitation history of natural areas for recreational activities, residents of these places have been excluded. Community organization is, however, a determining factor for the permanence and resistance of groups 
in their territories, over which they have indigenous knowledge (LEFF, 2016).

The very notion of belonging to the environment should be closely linked to Paleontology. By awakening memories and knowledge, it can contribute to a more reflective participation, which stimulates the feeling of belonging to the natural and cultural heritage, through the succession of (paleo) territories which form a unique reality, with confrontation mechanisms, strategies and actions, rebellion, insurgency, rupture and transgression before conditions that Walsh (2017) calls silencing. These silences, imposed or strategic, arising from the hegemonic capitalist system, which destroys and expropriates nature, represses, criminalizes and violates individuals and knowledge, are also contained in claims, which point to cracks and ruptures in the patterns of power, enabling the decolonization possibility, or, at least, aiming at it (WALSH, 2017).

Thus, we think that the conflicts evidenced here consist of more complex relationships than it appeared at first. It is important, therefore, to think of these places as spaces of memory which allow reflection on the human experience over time. What is legitimized in these places (in museums, research centers, schools, etc.)? Is it what local communities really want to legitimize about their past? Are there, in these places, policies that aim to enrich society's relationship with its cultural assets, its collective memory and its heritage?

For Santos (2002), the common heritage of the community ends up being part of a counter-hegemonic globalization, for allowing new local, regional and national identities to emerge, claiming the right to their roots, involving social and power relations which produce local and located knowledge. It is necessary, therefore, to avoid the fixed idea of what is understood as Paleontology. If nowadays problems of Social Sciences are shared with Natural Sciences (SANTOS, 2006), it is necessary to reverse the commodification and objectification of populations in paleontological sites. To what extent can we, in fact, understand Paleontology in a current and contextualized way, if we keep a look away from the socio-environmental issues related to it?

For that matter, we propose to think Paleontology through questions and reflections that encourage collective actions in these spaces, which cannot be seen only as spaces for contemplating beauty and recording fossils of the distant past, apart from communities and their cultural manifestations. Local social movements can contribute to the management of these sites, in a struggle to strengthen participatory and integrated management of the population and the use of their land, against the process of deterritorialization and reterritorialization. Environmental struggle as common good struggle.

In paleontological sites open to tourism, for example, thinking about communitybased tourism, which incorporates the way of living and the representation of the community's world, rooted in the participation and social protagonism of local populations (BURGOS; MERTENS, 2015), can be a strategy to face the market perspective which disrupts local culture, de-characterizes natural environments, raises social inequalities and encourages real estate speculation.

Political Ecology helps us to be suspicious of cherished ways of building and legitimizing conventional sciences, starting from a search for the identity of Latin American critical thinking, which can only find answers through the analysis of our past (ALI- 
MONDA, 2017; OLIVEIRA, 2018). Still for Alimonda (2017), if we have a common geo-historical reality, as Latin America, we need critical, anti-positivist thinking, to place us in a bordering position in relation to the established knowledge systems.

When it comes to geo-historical reality, the possibility of being in a new geological epoch, the Anthropocene, brings global warming as just one of the concerns that we must have in relation to the environmental crisis, while the threats of fascism and pandemics are current and real dangers. The Covid 19 pandemic, caused by the new Coronavirus, SARS-CoV2, highlights differences in risk exposure levels and the possibilities of coping with it, enhancing class division and vulnerabilities existing in this economic model (HARVEY, 2020). That is why for Harvey $(2020$, p. 15), there is no real natural disaster. "Viruses change all the time. But the circumstances in which a mutation becomes a threat to life depend on human actions".

In the middle of this current and catastrophic conjuncture, in an encounter between Earth and World, Social Sciences help us to think, critically, about the Capitalocene. It takes the space-time constituted by stories and practices of coexistence of multispecies that walk together, albeit in different contexts, in the midst of a complex framework of global processes. At each site, people with different cultures, different confrontations for socio-environmental issues which occur in the relationship among the environment, tourists, businessmen, geoscientists, managers and the local community. But it is necessary to cry for small spaces, for cracks, giving visibility to injustices and struggles (WALSH, 2017), sowing new connections, new possibilities, new alternative ways of thinking about alternatives.

\section{Final Considerations}

Stemming from the environmental conflicts found in the paleontological/speleological sites in Minas Gerais, it was possible to make connections with Political Ecology and Environmental Justice, in order to contribute to the visibility of issues which arise in communities with a rich natural and cultural heritage. By bringing up conflicting relationships, belonging to or valuing (paleo)territories, these connections are references for the fight against social inequality in these sites and the inclusion of their communities in participatory management.

We consider a change in the ways of viewing Brazilian paleontological/speleological sites and the relationships established in them with the surrounding communities urgent. This is also an attempt to overcome the fragmentation between Natural Sciences and Social Sciences (and Humanities), technological determinism and the invisibility of the communities which constitute these sites. More than overcoming neutrality, it is crucial for Paleontology to be a socio-environmental resistance space, seeking to transform individuals and society.

In this environmental and civilization crisis context, visualizing socio-environmental issues is also looking at community participation, empowering the struggle of the communities which hold this heritage. Trying to understand the environmental conflicts 
which occur in these spaces, grouping them and showing their singularities is an important path towards the decolonization of territories and paleoterritories which have historically been considered stages of social inequalities and environmental injustices.

In this regard, Political Ecology and Environmental Justice are necessary in a Capitalocene in which unprecedented issues, such as the global impact of the new coronavirus and science denial, call for urgent strategies for resistance and confrontation. Regarding fossils which are indisputable evidence of an ever-evolving planet Earth, contextualization and criticism allow us to prove ourselves able to analyze the correlation of interests as well as economic, political and social forces, linked through the power relations behind the denial of that knowledge.

We hope that the struggle for these territories may one day transcend the resource being defended here, and that the paleontological heritage will be a real driving force for the fight for various rights. As Ecléa Bosi (2003) would say, the link with the past helps us to extract the strength for the formation of our identity. After all, "the present is marked by a breath of air that was breathed before and by echoes of voices that were muted" (BENJAMIN, 1994, p. 223).

By revealing itself contemporary, in academic and social circles, Paleontology unites past and present, in spaces where different times coexist, and in a time in which different spaces are disputed. All in the same time and in the same space, and all in a different space-time, where struggles and disputes take place. We hope that this new proposal for Paleontology can gain more and more power, even though the journey which articulates such areas is just beginning. May the footprints put here today leave their mark on future hikes.

\section{References}

ACSELRAD, H. Ambientalização das lutas sociais - o caso do movimento por justiça ambiental. Estudos Avançados. São Paulo, SP: Universidade de São Paulo, p. 24-68, 2010.

ALIMONDA, H.; PÉREZ, C.T.; MARTÍN, F. (Coords.). Ecologia política latinoamericana: pensamento crítico, diferencia latino-americana y rearticulación espistémica. 1. ed. Ciudad Autónoma de Buenos Aires: CLACSO, 2017. v.2.

BENJAMIN, W. Obras escolhidas. Magia e técnica, arte e política, São Paulo: Brasiliense, 1994.

BOSI, E. O tempo vivo da memória: ensaios de psicologia social. São Paulo: Ateliê Editorial, 2003.

BRASIL. Decreto-Lei $\mathbf{n}^{\circ}$ 4146, de 4 de março de 1942. Dispõe sobre a proteção dos depósitos fossilíferos. Disponível em: <http://www.planalto.gov.br/ccivil_03/Decreto-Lei/1937- $1946 /$ Del4146.htm> Acesso em: 15 out. 2019.

BRASIL. Constituição (1988). Constituição da República Federativa do Brasil. Brasília, DF: Senado Federal, 1988. 
BRASIL. Lei no 13.575, de 26 de dezembro de 2017: cria a Agência Nacional de Mineração (ANM) em detrimento do Departamento Nacional de Produção Mineral (DNPM). Disponível em: < http://www.planalto.gov.br/ccivil_03/_Ato2015-2018/2017/Lei/L13575.htm> Acesso em: 06 maio 2020.

BRILHA, J.B.R. A Importância dos Geoparques no Ensino e Divulgação das Geociências. Revista do Instituto de Geociências - USP. São Paulo, Publicação Especial, v.5, p. 27-33, 2009.

BULLARD, R. Ética e racismo ambiental. Revista Eco 21, 2005.

BURGOS, A.; MERTENS, F; Os desafios do turismo no contexto da sustentabilidade: as contribuições do turismo de base comunitária. Pasos: Revista de Turismo y Patrimonio Cultural, v.13, n.1, p. 57-71, 2015.

CARDOSO, D. et al. Espacialidades e Ressonâncias do patrimônio cultural: reflexões sobre identidade e pertencimento. Revista de Geografia e Ordenamento do Território (GOT), n.11. p. 83-98, 2017.

CARVALHO, I.S.(Ed.). Paleontologia. Ed. Interciência, v.1, p. 833-861, 2004.

DEUS, J.A.S. de; FERREIRA, C.C.D.; RODRIGUES, R. S. Preservação da área cárstica de Lagoa Santa, MG, através da Educação Ambiental. Revista Geonomos, 1997.

ESCOBAR, A. Desde abajo, por la izquierda, y con la tierra: la diferencia de Abya Yala/ Afro/ Latino/ America. In: ALIMONDA, H.; PÉREZ, C.T.; MARTÍN, F. (Coords.). Ecología política latino-americana: pensamiento crítico, diferencia latinoamericana y rearticulación epistémica. 1ed. Ciudad Autónoma de Buenos Aires: CLACSO, 2017, v.1.

GODINHO, C.P. et al. Conflitos Ambientais e as contradições do desenvolvimento sustentável: o caso da mineração em Conceição do Mato Dentro - MG e suas consequências. In: XX Encontro Nacional de Estudo Populacionais, 1016, Foz do Iguaçu, Paraná. Anais... Associação Brasileira de Estudo Populacionais - ABEP, 2016.

HAESBAERT, R. Da desterritorialização à multiterritorialidade. Boletim Gaúcho de Geografia, v. 29, p.11-24, 2003.

HARAWAY, D. Staying with the Trouble. Making Kin in the Chthulucene. Durham: Duke University Press, 2016.

HARVEY, D. Política anticapitalista em tempos de COVID-19. In: DAVIS, M. et al: Coronavírus e a luta de classes. Terra sem Amos: Brasil, 2020.

IGLESIAS-RÍOS, R. Capitaloceno: a era da barbárie. 1 ed. Rio de Janeiro: Yellow Carbo Design e Publishing, 2019.

LANDER, E. (Org.). A colonialidade do saber: eurocentrismo e ciências sociais. Perspectivas latinoamericanas. Colección Sur Sur, Ciudad Autónoma de Buenos Aires: CLACSO, 2005. 
LEFF, E. A aposta pela vida: Imaginação sociológica e imaginários sociais nos territórios ambientais do sul. Petrópolis, RJ: Vozes, 2016.

LOPES, L.A.M. Os impactos socioculturais e o desenvolvimento do turismo paleontológico em Peirópolis - MG. Dissertação (Mestrado em Turismo e Meio Ambiente) - Centro Universitário UMA, Belo Horizonte, 2008.

LÖWY, M. Crise Ecológica, Crise Capitalista, Crise de Civilização: a alternativa ecossocialista. Caderno CRH, Salvador, v. 26, n. 67, p. 79-86, 2013.

MARTÍNEZ-ALIER, J.M. O ecologismo dos pobres: conflitos ambientais e linguagens de valoração. 2.ed. São Paulo: Contexto, 2015.

MARTINS, F.S.P. A Arqueologia no Brasil - Direito e Aplicabilidade. O Estudo de Caso do Sítio Arqueológico de Bisnau. Trabalho de Conclusão de Curso (Pós-Graduação Lato Sensu em Análise Ambiental e Desenvolvimento Sustentável) Centro Universitário de Brasília - UNICEUB/IOPD, Brasília, 2016.

MOURA-FÉ, M.M. Geoturismo: uma proposta de turismo sustentável e conservacionista para a Região Nordeste do Brasil. Sociedade e Natureza. Uberlândia, MG, v. 27, n.1, p. 53-66, 2015.

OLIVEIRA, R.R. Saberes tradicionais e a história da paisagem. In: SANTOS, M.G.; QUINTEIRO, M. (Org.). Saberes Tradicionais e locais: reflexões etnobiológicas. Rio de Janeiro: UERJ, 2018.

PADOAN, L. de L.F.; SOUZA, L.V. de. Contexto Socioambiental do Parque Estadual do Sumidouro, APA Carste de Lagoa Santa, MG. Uso Público em Unidades de Conservação, v.1, n.1, 2013.

PORTO-GONÇALVES, C.W. De Saberes e de Territórios: Diversidade e Emancipação a partir da experiência latinoamericana. In: CECEÑA, A,E. (coord.). De los saberes de la emancipación y de la dominación 1 ed. Buenos Aires: Consejo Latinoamericano de Ciências Sociales: CLACSO, 2008.

SANTOS, B.S. (Org.). A Globalização e as Ciências Sociais. São Paulo: Cortez, 2002

SANTOS, B.S. Conocer desde El Sur: Para una cultura política emancipatória. Lima, Peru: Fondo Editorial de la Facultad de Ciencias Sociales - UNMSM, 2006.

SANTOS, W.F.S.; CARVALHO, I.S.; FERNANDES, A.C.S. Mineração versus Paleontologia: Uso e Ocupação da Serra do Veadinho em Peirópolis - Uberaba, Estado de Minas Gerais (Brasil). Anuário do Instituto de Geociências - UFRJ, Rio de Janeiro, 2010.

SCHOBBENHAUS, C. et al. Sítios Geológicos e Paleontológicos do Brasil. DNPM/CPRM - Comissão Brasileira de Sítios Geológicos e Paleobiológicos (SIGEP) - Brasília, 2002.

SILVA, C.N.; COSENZA, A. A Paleontologia em Minas Gerais: turismo, conflitos socioambientais e Educação Ambiental. In: X XII Encontro Nacional de Pesquisa em Educação em Ciências 
- XII ENPEC, 2019, Natal, RN. Anais... Associação Brasileira de Pesquisa em Educação em Ciências - ABRAPEC, 2019a.

SILVA, C.N.; COSENZA, A. Paleontologia e Educação Ambiental: Possibilidades e desafios para o ensino e a justiça ambiental. In: X Encontro Pesquisa em Educação Ambiental - EPEA. Anais... UFJF, MG; UFF, RJ; FFCLRP/USP, SP; 2017. Universidade Federal de Sergipe, São Crisóvão, SE. Anais... Universidade Federal de Sergipe, São Crisóvão, SE, 2019b.

SOLÓRZANO, A; OLIVEIRA, R.R. de, GUEDES-BRUNI, R.R. Geografia, história e ecologia: criando pontes para a interpretação da paisagem. Ambiente $\mathbb{Q}$ Sociedade. Campinas, v.12, n.1, p.49-66, 2009.

VALLEJO, L.R. Uso público em áreas protegidas: atores, impactos, diretrizes de planejamento e gestão. Revista Eletrônica Uso Público em Unidades de Conservação. Niterói, RJ. v.1, n.1, 2013.

WALSH, C. (Ed.). Pedagogías decoloniales: prácticas insurgentes de resistir, (re)existir y (re) vivir. Tomo II. Quito, Ecuador: Ediciones Abya-Yala, 2017.

ZHOURI, A.; LASCHEFSKI, K. Desenvolvimento e Conflitos Ambientais: um novo campo de investigação. In:_ (Org.). Desenvolvimento e Conflitos Ambientais. Belo Horizonte: Editora UFMG, p.11-34, 2010. 


\section{Camila Neves Silva}

$\checkmark$ camilaneves.bio@gmail.com

ORCiD: https://orcid.org/0000-0001-7874-9271
Submitted on: 29/05/2020

Accepted on: 16/03/2021

2021;24e:00892

\section{Angélica Cosenza}

$\varangle$ ar_cosenza@hotmail.com

ORCiD: https://orcid.org/0000-0001-5412-5894

How to cite: SILVA, C.N.; COSENZA, A. Paleontology and environmental justice: making connections through political ecology. Ambiente $\&$ Sociedade. São Paulo, v. 24, p. 1-22, 2021. 


\title{
Paleontologia e Justiça Ambiental: tecendo conexões através da Ecologia Política
}

\author{
Camila Neves Silva \\ Angélica Cosenza
}

São Paulo. Vol. 24, 2021

Artigo Original
Resumo: Longe de tratar apenas de seres pretéritos, a Paleontologia é uma ciência atual, que pode situar a existência humana no contexto da crise ambiental global, frente a desigualdades e conflitos socioambientais que ocorrem nos sítios paleontológicos brasileiros. Objetivando discutir possíveis tessituras entre Paleontologia e Justiça Ambiental, este ensaio parte de um levantamento sobre os conflitos ambientais existentes nos sítios paleontológicos de Minas Gerais. A partir das questões encontradas, e com o aporte do referencial teórico da Ecologia Política, discutem-se a luta pelo território e pela decolonialidade, enquanto dimensões cruciais para um olhar que busque restituir às populações o direito aos seus (paleo)territórios. As conexões entre os campos são aqui situadas como referenciais para a luta contra a desigualdade social encontrada em sítios paleontológicos, a exemplo dos de Minas Gerais, e pela inclusão de suas comunidades em uma gestão participativa.

Palavras-chave: Conflitos Ambientais; Sítios Paleontológicos; Ecologia Política.

Como citar: SILVA, C.N.; COSENZA, A. Paleontologia e Justiça Ambiental: tecendo conexões através da Ecologia Política. Ambiente \& Sociedade. São Paulo, v. 24, p. 1-18, 2021. 


\title{
Paleontología y Justicia Ambiental: haciendo conexiones a través de la Ecología Politica
}

\author{
Camila Neves Silva \\ Angélica Cosenza
}

São Paulo. Vol. 24, 2021

Artículo original
Resumen: En lugar de solo lidiar con seres pasados, la Paleontología es una ciencia actual, que puede situar la existencia humana en el contexto de la crisis ambiental global, frente a las desigualdades y los conflictos socioambientales que ocurren en sitios paleontológicos brasileños. Para discutir posibles conexiones entre Paleontología y Justicia Ambiental, este ensayo parte de una investigacion sobre los conflictos ambientales existentes em sitios paleontológicos de Minas Gerais. Con base en los problemas encontrados, y con la contribución del marco teórico de la Ecología Política, se discute la lucha por el territorio y la descolonialidad para buscar restaurar a las poblaciones el derecho a sus (paleo) territórios. Las conexiones entre los campos son aquí referenciales para la lucha contra la desigualdad social en sitios paleontológicos, como los de Minas Gerais, y para la inclusión de sus comunidades en la gestión participativa

Palabras-clave: Conflictos Ambientales; Sitios Paleontológicos; Ecologia Política..

Como citar: SILVA, C.N.; COSENZA, A. Paleontología y Justicia Ambiental: haciendo conexiones a través de la Ecología Política. Ambiente $\&$ Sociedade. São Paulo, v. 24, p. 1-18, 2021.

DOI: http://dx.doi.org/10.1590/1809-4422asoc20200089r2vu2021L3AO 